\title{
GCU
}

Glasgow Caledonian

University

University for the Common Good

\section{Ethnic identity and perceptions of the police in Turkey: the case of Kurds and Turks}

\section{Sahin, Osman; Akboga, Sema}

Published in:

Policing and Society

DOI:

10.1080/10439463.2018.1477777

Publication date:

2019

Document Version

Author accepted manuscript

Link to publication in ResearchOnline

Citation for published version (Harvard):

Sahin, O \& Akboga, S 2019, 'Ethnic identity and perceptions of the police in Turkey: the case of Kurds and

Turks', Policing and Society, vol. 29, no. 8, pp. 985-1000. https://doi.org/10.1080/10439463.2018.1477777

\section{General rights}

Copyright and moral rights for the publications made accessible in the public portal are retained by the authors and/or other copyright owners and it is a condition of accessing publications that users recognise and abide by the legal requirements associated with these rights.

Take down policy

If you believe that this document breaches copyright please view our takedown policy at https://edshare.gcu.ac.uk/id/eprint/5179 for details of how to contact us. 
Accepted by Policing \& Society in May 2018

Ethnic identity and perceptions of the police in Turkey: the case of Kurds and Turks

Osman Sahin*

International Relations, Nisantasi University

Hasbahce Cad. No.88

34406 Kagithane / Istanbul

osman81sahin@gmail.com

+90 5332397598

Sema Akboga

Political Science and Public Administration, Istanbul Medipol University,

Kavacik Mah. Ekinciler Cad. No: 19 Beykoz Istanbul, Turkey

semaakboga@gmail.com

+905357019122

*Corresponding author

\section{Acknowledgments}

We would like to thank Christopher Einolf, Ekrem Karakoç, and Engin Arik for their critical and useful comments on earlier drafts of the paper as well as Ali Çarkoğlu, Ersin Kalaycıoglu, and Tarcan Kumkale for their useful comments during the construction of the survey instrument.

\section{Funding}

This work was funded by The Scientific and Technological Research Council of Turkey (TÜBİTAK) under Grant 113K522. 


\title{
Ethnic identity and perceptions of the police in Turkey: the case of Kurds and Turks
}

\begin{abstract}
Drawing on the literature on minorities' and ethnic groups' perceptions of the police, this article investigates the differences between Kurds and Turks in terms of their perceptions of the police in Turkey. We conducted survey research using a nationally representative sample of 1,804 people. Multivariate regression analysis revealed that Kurds in Turkey have a more negative perception of the police than Turks, regardless of their gender, education, income, party affiliation, and sectarian identity. It is concluded that the historical relationship between Kurds and the Turkish state has had a decisive effect on how Kurds perceive the police.
\end{abstract}

Keywords: Turkey; ethnic identity; Kurds; perceptions of the police

\section{Introduction}

The nature of the relationship between the police and different societal actors is determined by a variety of factors. This includes historical factors and state policies, which can influence the nature of this relationship. Turkey is an interesting case in this respect, as its history is rich with contentious encounters between the state and various ethnic groups (Yegen 2009; Aslan 2011; Guttstadt Görgü 2013). Although claims as to the nature of the relationship between these groups and state institutions abound, they are rarely backed by empirical research. Drawing on existing literature on conflict theory, group position theory, and police legitimacy, this article studies the differences between Kurds and Turks in terms of their perceptions of a major state institution: the police in Turkey.

Although Kurds are not legally defined as an ethnic minority in Turkey, they constitute the second largest ethnic group, after Turks. The Turkish state has denied Kurds' cultural and political rights emanating from their identity and has adopted assimilationist policies since the founding of the Republic in 1923 (Yegen 2009). For example, after the 1980 military coup, which was especially decisive in shaping Kurds' relationship with the state, Turkey banned the Kurdish language in public life and the media (Kizilkan Kisacik 2014). After a full-scale conflict broke out between security forces and the Kurdistan Workers' Party (Partiya Karkeren KurdistanePKK), the Turkish state declared martial law in the largely Kurdish southeast from 1987 to 2002, exacting a heavy toll on the Kurds.

During the 1990s, the Turkish army forcibly displaced approximately 400,000 Kurds (Çelik 2005), which not only swelled the ranks of the urban poor in the southeast of Turkey, but also created a highly polarized third wave of Kurdish migrants and refugees across Europe (Canefe 2008). This era witnessed many human rights violations by the Turkish state, including violations of the right to life and property. The Turkish state failed to provide food, temporary housing, and medical care for displaced Kurds (Çelik 2005). Disappearances, extrajudicial executions, arbitrary detentions, and torture were very common during this period (Kizilkan Kisacik 2014). Approximately 1,353 people disappeared between 1980 and 2001 by forces connected with the state, and thousands of murders remain unsolved (Göral et al. 2013). Responsible security forces and administrative personnel were not investigated, tried, or held accountable. When a disappeared person was tortured to death, the state 
claimed that this person had died in armed clashes; the records of their deaths were falsified, sustained by fake evidence. The state's response to the disappearances included threats to the relatives of those who had disappeared, as well as denial of the fact that the person had disappeared while in the custody of security forces (Göral et al. 2013).

Based on the above short historical review of the relationship between Kurds and the Turkish state, we propose that Kurds are more likely than Turks to view state institutions as oppressive and less legitimate, due to their problematic relationship with the state. Research also shows that Turks' negative attitudes towards Kurds are stronger than Kurds' negative attitudes towards Turks (Sarigil and Karakoç 2016, Bilali et al. 2014, Çelik et al. 2017). This may be a result of the fact that Turks feel superior to Kurds and view them as a threat to their interests (Saracoglu 2009, 2010). Hence, Turks have an interest in maintaining the existing social and political order, leading them to see state institutions such as the police as their ally against Kurds. Kurds, however, do not have any vested interest in maintaining the existing order and therefore do not view state institutions as their allies. Indeed, research indicates that Kurds are less likely than Turks to trust state institutions (Karakoç 2013). Thus, based on conflict theory and group-position theory, as well as the literature on police legitimacy, we expect Kurds to have a more negative attitude towards the police, as they are more likely to be positioned against the state and see the police as the tool of the majority that contributes to their subordination. On the other hand, Turks have a more positive view of the police because they are more likely to be positioned alongside the state and therefore see the police as an ally that protects their interests.

To test these assumptions, a public opinion survey was conducted between March 4 and May 5 of 2015, using a nationally representative sample of 1,804 people. During the time of the surveys, negotiations between the Turkish state and Abdullah Öcalan, the imprisoned leader of the PKK, were ongoing, and a de facto ceasefire between the PKK and the Turkish state was still in place.

\section{Literature Review}

Previous research on the relationship between the police and citizens, as well as on the relationship between the police and ethnic minorities, provide various theoretical arguments. One such argument is based on conflict theory, which suggests that society consists of groups with different and competing values, and the state represents the interests of the dominant class (Sampson and Laub 1993). According to this perspective, criminal law protects the interests of the elite in society (Sampson and Laub 1993). The law is therefore imposed in a discriminatory fashion to protect dominant group's interests from threats posed by subordinate groups (Cureton 2000). The severity of criminal justice depends on a person's class or ethnicity, meaning that the poor and some ethnic groups are subjected to more pressure in order to ensure that the state can effectively control them (Sampson and Laub 1993). Regarding the police, conflict theory suggests that the police protect dominant groups' interests and control subordinate groups (Weitzer and Tuch 1999, Das 1983), resulting in a more negative view of the police by the subordinate group (Alpert and Dunham 1992). Minorities therefore view the police as instruments of the dominant ethnic group (Enloe 1980) and perceive the police as a symbol of the dominant majority that contributes to their oppression (Wortley and Owusu-Bempah 2009). 
There are a number of theories derived from conflict theory, including group position theory (Weitzer and Tuch 2006, Cochran and Warren 2012). Blumer's group position theory suggests that in addition to personal beliefs and feelings, an individual's sense of group position determines one's attitudes towards other racial groups (Blumer 1958). Accordingly, members of the dominant group feel a sense of superiority, leading them to view members of the subordinate group as rivals (Bobo and Tuan 2006), and therefore act to protect their interests in keeping the existing racial order (Weitzer and Tuch 2006). Although group position theory has been used to explain ethnic groups' attitudes towards other groups, Weitzer and Tuch (2006) extend it to understand a group's relationships with social institutions, using the example of the differences between minorities and whites in the U.S. in terms of their views regarding the police. They argue that 'if the dominant group believes that it is entitled to valuable resources, it follows that the group should have an affinity with the institutions that serve their interests' (p. 8). In other words, their extension of the group position theory suggests that people's views of social institutions are influenced by the interests of their groups and the perceived threats against them (Weitzer and Tuch 2006). In relation to the police, they argue that 'as a general rule, dominant racial groups see the police as an institution allied with their interests, whereas minorities are inclined to view the police as a force that contributes to their subordination' (p. 185). Especially in divided societies, as Brewer (1991, p. 182) argues, 'subordinate groups view the police as agents of oppression or occupation and show a minimal commitment to them, while the dominant community tends to look on the police as its own and the guarantor of its position'. This is because in divided societies, the police, due to their partisan methods, unrestrained use of force, and their interventions in the lives of minorities, contribute to existing conflict, while attempting to achieve internal security (Brewer 1991).

Another line of research uses 'procedural justice' in order to understand police-citizen relations. Tyler (2005) argues that people's perceptions of the police are determined by their perceptions of procedural justice, which refers to the extent to which the police treat citizens fairly during an encounter. When people evaluate procedural justice, 'they consider factors unrelated to outcome, such as whether they have ... been treated with dignity and respect' (Tyler 1990, p. 178). Therefore, a minority group that believes that they are being treated more harshly than the majority group will have a more negative view of the police (Weitzer and Tuch 1999, Van Craen 2012). The procedural justice perspective also suggests that people's evaluations of the fairness of the procedures the police use while exercising their authority will determine their views about the legitimacy of the police (Sunshine and Tyler 2003). As minorities generally believe that they are treated unfairly by the police (Browning et al. 1994, Eschholz et al. 2002), they tend to view the police as less legitimate (Weitzer and Tuch 1999, Tyler 2005).

However, other scholars argue that perceptions of police legitimacy are not simply influenced by perceptions of procedural justice. Criticizing the procedural justice perspective for being one-sided, some suggest that the process of interaction involves not only how the police behave, but also how people perceive and interpret that behavior (Waddington et al. 2013). Skogan (2012, p. 276) argues that the mental frame imposed upon the encounter from the beginning could easily color citizens' perceptions of police behavior. Therefore, if a minority group does not believe the police have a legitimate claim to exercise power, their attitudes towards the police 
could be negative, regardless of the fairness of police behavior. According to Manning (2010), police legitimacy may be influenced by social and political contexts. For example, political and ethnic cleavages could be important in understanding the ways in which the police are judged by the public (Roche and Roux 2017). Particularly in divided societies, people's allegiance to or alienation from the state shapes their relationship with the police (Marenin1985, Roche et al. 2017). ${ }^{1}$ Previous research has demonstrated that the strength of people's identification with the state, which may be influenced by their ethnic identity (Spehr and Kassenova 2012), determines the degree to which they see the police as legitimate (Murphy and Cherney 2011, Bradford et al. 2014). This explains why ethnic minorities are more likely to be positioned against the state and are more likely to see the police as an agent of the state that contributes to their subordination. In Turkey, for example, Kurds grant less legitimacy to police misconduct than Turks (Roche et al. 2017).

Making a more general argument about people's perceptions of institutional authorities, Easton (1965) argues that deeply-held beliefs, or an inner conviction of the moral validity of authorities, encourage citizens to either accept or reject the validity of policy decisions. If citizens do not believe in the legitimacy and the uprightness of the institutions, they might not have a reservoir of goodwill for a particular institution, regardless of the fairness of that institution's decisions (Cann and Yates 2008). Along the same lines, Gibson (1991) suggests that perceptions of institutional legitimacy shape perceptions of procedural justice. In his words, 'views on the legitimacy of an institution reflect childhood socialization experiences and fundamental political values as well as accumulated satisfaction or dissatisfaction with the institution's policy outputs' (1991, p. 633). This is because legitimacy, which refers to the recognition of moral authority, provides a framework through which citizens view social and political arrangements as rightful (Fisk and Cherney 2017).

An authority is legitimate to the extent that (1) it is acquired and exercised in accordance with established rules; (2) the rules are justifiable according to sociallyaccepted beliefs about the rightful source of authority; and (3) positions of authority are confirmed by expressed consent and recognition from other legitimate authorities (Beetham 1991). In formulating the hypotheses below, this article draws on the first principle, which is also referred to as lawfulness, meaning that the powers that allow police officers to do certain things should be consistent with preexisting law (Tankebe 2013). In other words, the police should act in a manner that is 'unbiased, free of passion, prejudice, and arbitrariness, loyal to the law alone' (Tamanaha 2004, p. 123).

Existing research on various societies revealed differences among ethnic communities in terms of their perceptions of the police. Across English and non-English speaking countries, it was found that minority groups have poorer perceptions of the police than the majority. For instance, in the U.S., blacks are more likely to have negative perceptions of the police than whites (Wu 2014, Rosenbaum et al. 2005, Rocque 2011, Buckler and Unnever 2008). In Canada, minorities such as Chinese, blacks, and non-English speaking people hold more negative views of the police than whites and other English-speaking people (Wortley 1996, Wortley and Owusu-Bempah 2009, O'Connor 2008). In Britain, too, ethnic minorities have more negative views of the police than the majority (Bradford et al. 2009, Chakraborti and Garland 2003).

Studies conducted elsewhere also demonstrate that ethnic minorities are more likely 
to hold negative perceptions of the police. In Germany, the majority of Turkish youth feel discriminated against by the police because of their ethnic background (Albrecht 1997). In France and Belgium, ethnic minorities have more negative attitudes towards the police than the majority (European Union 2010, Dhont et al. 2010). Catholics in Northern Ireland do not completely trust the police (McGloin 2003, Northern Ireland Policing Board Report 2016). In South Africa, black South Africans are less satisfied with the police than white South Africans (Lehohla 2015). In China, the dominant ethnic group (those of Han nationality) has greater confidence in the police (Cao and Hou 2001). Similarly, Arabs in Israel view the police more negatively than Jews (Hasisi and Weitzer 2007).

Previous research also suggests that socio-demographic factors such as age, gender, income, and education have an effect on people's attitudes towards the police. Research on the effects of age on attitudes towards the police produced mixed results. While Brown and Benedict (2002) observed a positive effect of age on perceptions of the police, Myhill and Bradford (2012) observed a negative effect. Kusow et al. (1997), on the other hand, found no effect of age on attitudes towards the police. Regarding gender, Lai and Zhao (2010) found that men hold more negative views of the police than women, while other studies showed that women have less favorable views about the police (Correia et al. 1996).

Findings regarding the effects of income and education on people's perceptions of the police are also ambiguous. Whereas some studies documented that people with lower incomes are more likely to have negative views of the police (Kaarianinen 2007), others showed that those with higher incomes are more likely to have negative views of the police (Cao and Zao 2005). Other studies did not indicate an effect of income on people's perceptions of the police (Jang et al. 2010). Regarding education level, some studies found that people with higher levels of education have more positive attitudes towards the police (Frank et al. 2005), while others showed a negative effect of education (Weitzer and Tuch 1999, Smith 2005).

Studies regarding people's perceptions of the police in Turkey are limited. The World Values Survey (WVS), an important source for understanding people's trust in the police in Turkey, measures the public's trust in police with only one question. ${ }^{2}$ According to the 2012 WVS, $37.8 \%$ of the Turkish public reported a great deal of confidence in the police, $36.6 \%$ reported quite a lot of confidence, $14.4 \%$ reported not very much confidence, and $9.8 \%$ reported no confidence at all. Another study conducted by Kırmızıdağ in 2015 found that people's trust in the police in Turkey is generally positive (with a score of 3.89 out of 5), and revealed that Sunnis and Turks held more positive views concerning the legitimacy of the police than Alevis and Kurds. This study did not examine Alevi Kurdish people's perceptions of the police. Significantly, however, rather than examining general perceptions of the police, the Kırmızidağ study investigated views on more specific issues such as the effectiveness of the police, as well as cooperation with and obedience to the police. Using the data collected by Kurmizidağ, Roche et al. (2017) showed that social and political cleavages such as political party preferences, and ethnic and religious identities form the main basis upon which the right to use deviant means is granted to the police. They also revealed that Alevis, Kurds, and opposition party voters are less likely to approve of police misconduct in Turkey. 


\section{Research Hypotheses}

According to Roche et al. (2017), citizens' relationship with the police is shaped by their general relationship to the state. When citizens hold collective grievances against the state and feel estranged, they feel less represented, which, in turn, negatively affects their relationship with the police (Roche et al. 2017). Particularly in transitional and divided societies such as Turkey, loyalty to the state shapes people's relationship with the police more deeply than in other contexts (Roche et al. 2017). Previous research, for example, demonstrates that the strength of people's identification with the state (Murphy and Cherney 2011), as well as the political and social context of the country (Manning 2010), might affect the degree to which they see the police as legitimate. Hence, a problematic history between a particular ethnic group and the state might undermine the legitimacy of the police in the eyes of the ethnic group that has been routinely discriminated against, especially when they perceive the state to be untrustworthy (Bradford et al. 2014). The problematic history of the relationship between Kurds and the Turkish state, therefore, may have caused Kurds to lose trust in the state and to identify less with the state, which may lead them to see the police as agents of oppression who are protecting Turks' position. Thus, drawing on both group position theory and the literature on police legitimacy, we argue that Kurds are less likely than Turks to perceive the police as legitimate, since they are more likely to be positioned against the state and to believe that the police protect the interests of the Turkish majority against Kurds. Kurds therefore are more likely to assume that the police do not act in accordance with existing laws in their interactions with Kurds. In other words, Kurds may think that police actions towards Kurds violate the principle of lawfulness, one of the conditions of legitimacy proposed by Beetham (1991), which suggests that authority is legitimate only to the extent that it is acquired and exercised in accordance with established rules. Kurds may believe that the manner in which the police exercise power towards them is not compatible with this principle of legitimacy. This leads them to hold more negative perceptions of the police. We therefore hypothesize that:

$H_{1}$ : In Turkey, Kurds have a more negative perception of the police than Turks.

Previous research has also demonstrated that ethnic minorities' place of residency is an important determinant of their perceptions of the police (Kusow et al. 1997, Bjornstrom 2015). Diyarbakır is a major political and cultural hub for the Kurdish movement in Turkey and therefore has witnessed several violent encounters between locals and security forces, as well as between the PKK and the police, causing both Turks and Kurds residing in Diyarbakır to be more politicized than those living in other cities in Turkey. The literature also suggests that a higher level of police presence might negatively affect people's perceptions of the police (Koper 1995). In Diyarbakır, there is one police officer for every 168 people, while in Istanbul, the largest city in Turkey, this figure stands at one police officer for every 355 people (Sözcü 2015). We therefore hypothesize that:

$\mathrm{H}_{2}$ : People living in Diyarbakır have a more negative view of the police than people living in other cities. 
Whether a Kurd identifies as Sunni ${ }^{3}$ or Alevi ${ }^{4}$ may have an effect on their perceptions of the police because of the problematic relationship between the state and Alevis in Turkey. During the 1970s, state security forces considered Alevis to be a major threat to the state, along with communism and Kurdish separatism (Erdemir 2005). Promoting Sunni Islam, the Turkish state targeted Alevis with assimilationist policies, which gained pace after the 1980 coup (Acikel and Ates 2011), causing Alevis to become alienated from the state, a process that continues well into the late 2010s. These assimilation policies include compulsory religious classes based on Sunni teachings, opening mosques in Alevi villages, and refusing to recognize cemevis as official prayer houses. In divided societies such as Turkey, people's alienation from or loyalty to the state shapes their relationship with the police (Marenin 1985, Roche et al. 2017). We therefore expect that Alevi Kurds would be more averse to the police than Sunni Kurds, as Alevi Kurds feel more alienated from the state for being both Kurdish and Alevi. Hence, we hypothesize that:

\section{$H_{3}$ : In Turkey, Alevi Kurds have a more negative perception of the police than Sunni Kurds.}

\section{Methods}

Because this study aims to understand Kurds' and Turks' perceptions of the police in Turkey, we used survey methodology, which enabled us to reach a much greater number of people compared to qualitative methods such as interviews. Random sampling was used in order to generalize the survey results to the overall population.

\section{Data}

The data of this research is drawn from a national survey funded by the Scientific and Technological Research Council of Turkey (TUBITAK). The survey was conducted through random sampling with 1,804 people at least 18 years of age. Of 1,804 people, $1,401(77.7 \%)$ identified themselves as Turks, $334(18.5 \%)$ identified themselves as Kurds, and $69(3.8 \%)$ either did not declare an ethnic identity or associated themselves with identities other than Kurd or Turk. ${ }^{5}$

While determining the sub-regions for sampling, this study used the Turkish Statistical Institute's (TUIK) NUTS-12 system that divides Turkey into 12 regions. In this classification, 81 provinces of Turkey are classified based on their geographical location and socio-economic qualities (see Appendix 1 for details). The number of participants in each of these sub-regions was determined in proportion to its population. Then, one city (urban center) and one rural and/or semi-rural center were chosen from each sub-region. Appendix 2 shows the number of survey participants from each sub-region, along with the names of cities in parentheses.

The questions analyzed in the current study were sourced from this national survey aiming to measure people's perceptions of democracy, and the rule of law in Turkey. The questions concerning people's perceptions of the police were included in the rule of law section of the survey and were based on two sources: (1) interviews conducted with 60 people in five cities in Turkey (İstanbul, Kayseri, Adana, Trabzon, and Diyarbakır), and (2) the rule of law categories created by the World Justice Project ${ }^{6}$ (WJP). During the survey, participants were asked about their views on whether the 
police in Turkey treat everyone equally. Some of the questions in the survey were formulated based on the patterns detected in participants' responses during analysis of the interviews. WJP measures the rule of law using nine categories, including 'Criminal Justice,' which consists of seven sub-factors. Of these seven, two factors, 'criminal justice system is impartial' and 'due process of law and rights of accused' were used to create the survey questions. To check the consistency of measurements, a pilot study was conducted with 100 people in five different cities (İstanbul, Kayseri, Adana, Erzurum, and Diyarbakır). The survey questionnaire was finalized based on the results of the pilot survey and was conducted by the Optimist Research company, located in Istanbul where the researchers arranged an 8-hour training program for 12 field coordinators. During the training, field coordinators were informed about the goals and content of the survey. In addition, each survey question was extensively discussed and analyzed. The field coordinators, in turn, trained interviewers upon their return to their regions.

TUIK provided the research team with 180 randomly-sampled geographical areas. Interviewers working for this research project were directed to complete 10 interviews from each sampling unit, and the beginning address for each interviewer was randomly chosen by TUIK. After the initial survey, the interviewer then visited every third address to her right until 10 surveys were completed. In each address, the interviewer conducted the survey with the household member who is over 18 years old and whose name has an initial closest to the letter 'A'. 1,804 surveys were completed between March 4 and May 5 of 2015, and all were conducted face-to-face in participants' houses. Surveys were conducted in Turkish, which did not pose a barrier for Kurdish participants, as the great majority of Kurds in Turkey are bilingual. The participants did not receive any material or immaterial gain for their participation in this study. In order to obtain 1,804 participants, the research company approached 2,653 people, 804 of whom declined to be interviewed, and 45 of whom did not complete the interview. The overall response rate for the survey was $67.99 \%$.

\section{Variables}

\section{Dependent variable}

The dependent variable was created by using 5 scale questions. After being given five statements, participants were asked, 'to what extent do you agree with the following statement?', and were then asked to provide a number ranging between ' 1 ' and ' 5 ' for each statement. Reliability analysis demonstrated that these five questions produced a high Cronbach's alpha score (0.924) and formed a single dimension when entered into factor analysis. Therefore, through a simple summation procedure, a single composite variable consisting of these five variables was created. This variable was then divided by five to create the dependent variable, which is a scale between ' 1 ' and ' 5 '. The dependent variable, "Perception of the Police," was presented on a scale ranging between 1 and 5, indicating "totally disagree" and "totally agree," respectively, and consisted of the following statements: (1) I trust the police force in Turkey; (2) In Turkey, the police force does not discriminate between Kurds and Turks, nor between Alevis and Sunnis; ${ }^{7}$ (3) In Turkey, the police force does not discriminate between the poor and the rich; (4) In Turkey, the police force does not use violence against people who are under custody or interrogation; and (5) In Turkey, the police force does not conduct illegal wiretapping or property searches. 


\section{Independent variables}

The main independent variable, 'Kurdish Identity', was a dummy variable that corresponds to the following question: 'Which ethnic group do you belong to?' Those who chose the option 'Kurd' were coded as ' 1 ', while 'Turk' was coded as ' 0 '. Because the "Kurdish Identity" variable specifically aims to measure the differences between Kurds and Turks in terms of their perceptions of the police, 69 people who indicated that their ethnicity was neither Kurdish nor Turkish were coded as 'system missing'.

The second independent variable, also a dummy variable, was named 'Diyarbakır', which is a predominantly Kurdish city that has been significantly affected by the war between the PKK and Turkish security forces. In this study, people living in Diyarbakır were coded as ' 1 ', while people living in other cities were coded as ' 0 '.

The third independent variable was a dummy variable introducing the sectarian identity of Kurds. This variable aims to measure if Alevi Kurds' perceptions of the police significantly differ from those of Sunni Kurds. It was created with a simple multiplication procedure, where the Alevi identity $($ Alevi $=1$; Sunni $=0)$ was multiplied by the Kurdish variable $($ Kurd $=1$; Turk $=0)$. The resulting variable was a dummy variable named 'Alevi Kurd' (Kurdish Alevi Identity =1; Other =0).

\section{Control variables}

The first control variable is party preference. Research reveals that those who vote for winning political parties are more likely than those who vote for losing political parties to state that civil servants can be trusted to do the right thing (Anderson and Tverdova 2001). Because the police answer to the central government, proximity with the party in power explains attitudes towards the police in Turkey, unlike in nations with a decentralized police system (Roche et al. 2017). In order to determine participants' party preferences, they were asked the following question: 'If there were general elections next Sunday, which political party would you vote for?'. Those saying that they would either vote for or be more inclined to vote for the incumbent Justice and Development Party (AKP) were coded as ' 1 '. Those saying that they would either vote for or be more inclined to vote for parties other than the AKP were coded as ' 0 '. This variable was named 'Incumbent Party Voter' and was designed to measure whether being a supporter of the ruling party is related to people's perceptions of the police in Turkey.

Other control variables are socio-demographic variables: 'Age' (between 18 and 91), 'Female' (female $=1$; male $=0)$, 'Education' ( 1 = no schooling; $2=5$-year degree; 3 =8-year degree; $4=$ high school degree; $5=$ higher education degree), and 'Household Expenditure' $(1=$ under 500 Turkish Lira per month; $2=500-1000$ Turkish Lira per month; $3=1001-1500$ Turkish Lira per month; $4=1501-2500$ Turkish Lira per month; $5=2501-3500$ Turkish Lira per month; $6=3501-5000$ Turkish Lira per month; $7=5001-7000$ Turkish Lira per month; $8=$ over 7,000 Turkish Lira per month). The Household Expenditure variable measures participants' monthly household's expenditure, which is an indicator of their economic position in the population. 
Accepted by Policing \& Society in May 2018

\section{Results}

\section{Descriptive Statistics}

Table 1 and Table 2 summarize the descriptive statistics for all variables used in the analysis.

Table 1. Percentage frequency distribution of categorical variables $(\mathrm{N}=1804)$

\begin{tabular}{|l|c|c|}
\hline & All cases \% & Valid cases \% \\
\hline Male & 49.7 & 49.7 \\
\hline Female & 50.3 & 50.3 \\
\hline No Answer/ System Missing & 0 & \\
\hline Total & $\mathbf{1 0 0}$ & $\mathbf{1 0 0}$ \\
\hline Kurd & 18.5 & 19.3 \\
\hline Turk & 77.7 & 80.7 \\
\hline No Answer/ System Missing & 3.8 & \\
\hline Total & $\mathbf{1 0 0}$ & $\mathbf{1 0 0}$ \\
\hline Incumbent Party Voter & 28.7 & 37.5 \\
\hline Opposition Voter & 47.8 & 62.5 \\
\hline No Answer/ System Missing & 23.4 & \\
\hline Total & $\mathbf{1 0 0}$ & $\mathbf{1 0 0}$ \\
\hline Diyarbakir Resident & 10.6 & 10.1 \\
\hline Other City Residents & 89.4 & 89.4 \\
\hline No Answer/ System Missing & 0 & \\
\hline Total & $\mathbf{1 0 0}$ & $\mathbf{1 0 0}$ \\
\hline Alevi Kurds & 2.1 & 2.1 \\
\hline Other & 95.1 & 97.9 \\
\hline No Answer/ System Missing & 2.8 & \\
\hline Total & $\mathbf{1 0 0 \%}$ & $\mathbf{1 0 0 \%}$ \\
\hline
\end{tabular}

Table 2. Descriptive statistics for variables $(\mathrm{N}=1804)$

\begin{tabular}{|l|c|c|c|c|}
\hline & Minimum & Maximum & Mean & Standard deviation \\
\hline Perception of the Police & 1 & 5 & 2.75 & 1.17 \\
\hline Age & 17 & 91 & 38.76 & 13.67 \\
\hline Sex & 0 & 1 & .50 & .50 \\
\hline Household Expenditure & 1 & 8 & 3.31 & 1.22 \\
\hline Education & 1 & 5 & 3.25 & 1.23 \\
\hline Incumbent Party Voter & 0 & 1 & .38 & .48 \\
\hline Kurdish Identity & 0 & 1 & .19 & .39 \\
\hline Diyarbakır & 0 & 1 & .11 & .31 \\
\hline Alevi Kurd & 0 & 1 & .02 & .14 \\
\hline
\end{tabular}




\section{Multivariate linear regression results}

This study uses a multivariate regression analysis, the results of which are summarized in Table 3 below.

Table 3. Ethnicity and the perception of the police ${ }^{\text {a }}$

\begin{tabular}{|c|c|c|c|c|}
\hline & Model 1 & Model 2 & Model 3 & Model 4 \\
\hline Age & $.002(.002)$ & $-.005^{*}(.002)$ & $-.005^{*}(.002)$ & $-.005^{*}(.002)$ \\
\hline Female & $.044(.068)$ & $.004(.064)$ & $.004(.064)$ & $.008(.064)$ \\
\hline Household Expenditure & $.046(.072)$ & $-.007(.069)$ & $-.003(.068)$ & $-.006(.068)$ \\
\hline Education & $.056^{*}(.025)$ & $-.035(.025)$ & $-.044(.025)$ & $-.040(.025)$ \\
\hline Incumbent Voter & $1.307^{* * *}(.058)$ & $1.150^{* * *}(.056)$ & $1.140^{* * *}(.056)$ & $1.136^{* * *}(.056)$ \\
\hline Kurdish Identity & & $-.925^{* * *}(.074)$ & $-.766^{* * *}(.094)$ & $-.706^{* * *}(.104)$ \\
\hline Diyarbakır & & & $-.322^{*}(.120)$ & $-.365^{*}(.124)$ \\
\hline Alevi Kurd & & & & $-.257(.186)$ \\
\hline Constant & $1.897(.200)$ & $2.796(.202)$ & $2.832(.202)$ & $2.817(.202)$ \\
\hline Adjusted $\mathrm{R}^{2}$ & 0.285 & 0.363 & 0.366 & 0.366 \\
\hline Df & 1284 & 1283 & 1282 & 1281 \\
\hline
\end{tabular}

Dependent Variable: Perception of the Police

a. Entries are coefficients of multivariate linear regressions with standard errors in parentheses.

$* \mathrm{p}<0.05 ; * * * \mathrm{p}<0.001$

Model 1 includes Age, Education, Female, Household Expenditure, and Incumbent Party Voter variables. The Education variable has a significant effect in the model ( $\mathrm{p}$ $<0.05$ ). The more educated one is, the more likely one is to hold a positive perception of the police in Turkey. The analysis also indicates that being a voter for the governing party is positively associated with the dependent variable. AKP voters are more likely than opposition party voters to think positively about the police in Turkey ( $\mathrm{p}<0.001)$. Age, Female, and Household Expenditure variables do not have any significant effect in this model.

Model 2 introduces the main independent variable, Kurdish Identity. This variable has a negative and significant effect in the model. Kurds are more likely than Turks to have negative views about the police $(\mathrm{p}<0.001)$. This finding supports the first hypothesis that 'in Turkey, Kurds have a more negative perception of the police than Turks'. The Age variable becomes significant after the introduction of the Kurdish Identity variable to the model. Model 2 shows that older people are more likely than younger people to hold negative views about the police in Turkey $(\mathrm{p}<0.05)$. The Education variable, which had a significant effect in Model 1, has no significant effect in Model 2 after Kurdish Identity is introduced to the model.

In Model 3, the new variable is Diyarbakır. Its effect is negative and significant, 
indicating that people living in Diyarbakır have a more negative view of the police than people residing in other cities $(\mathrm{p}<0.05)$. Therefore, this model supports the second hypothesis that 'people living in Diyarbakir have a more negative view of the police than people living in other cities'. The effect of Kurdish Identity on the dependent variable is still significant after the introduction of the Diyarbakir variable $(\mathrm{p}<0.001)$.

In Model 4, the Alevi Kurd variable is introduced in order to measure whether Alevi Kurds are more averse to the police in Turkey than Sunni Kurds. The analysis showed that this variable has no significant effect on the dependent variable. Hence, the third hypothesis, stating that 'in Turkey, Alevi Kurds have a more negative perception of the police than Sunni Kurds', is not supported. Kurds' negative view of the police seems to have no relationship with their sectarian identity. Support for the governing party maintains its positive effect on people's perceptions of the police. The Kurdish Identity variable still has a negative effect on the dependent variable. Kurds are more likely than Turks to hold negative perceptions of the police $(\mathrm{p}<0.001)$. In Model 4 , the Diyarbakir variable still has a negative effect on the dependent variable $(\mathrm{p}<$ 0.05). Our findings therefore support $H_{1}$ and $H_{2}$ in Model 4, as well.

\section{Conclusion}

The major findings of this research can be summarized as follows: first, Kurds have a more negative perception of the police than Turks, supporting our first hypothesis. Second, people residing in Diyarbakır have a more negative perception of the police than people living in other cities, supporting our second hypothesis. Third, Kurds' sectarian identity does not have an impact on their perceptions of the police, failing to support our third hypothesis. Kurds, regardless of their sectarian identity, have a more negative view of the police. Fourth, incumbent party supporters in Turkey have a more positive perception of the police in Turkey. The fact that incumbent AKP voters have a more positive perception of the police than even Nationalist Action Party (MHP) voters, ${ }^{8}$ who are nationalist and historically supportive of the police, shows the robustness of this finding. Lastly, other than age, demographic factors do not explain the differences in the ways in which people view the police in Turkey. Our results therefore support the previous finding that there is a negative relationship between age and perceptions of the police, but do not support previous research claiming that income, education, and gender affect people's perceptions of the police.

Assimilationist policies of the Turkish state since the founding of the Republic, as well the war between the PKK and the Turkish army (including its consequences for the Kurdish people in the region since the 1980s), have created significant divisions between Kurds and the Turkish state. The Turkish state's policies, especially following the eruption of the conflict between the state and the PKK, set in motion a process in which the police and military acted as the state's agents of oppression. This, in turn, caused Kurds to lose their loyalty to and become alienated from the Turkish state. As the above literature reveals, people's alienation from the state, especially in divided societies, shapes their relationship with the police (Marenin 1985, Olivera and Murphy 2015, Roche et al. 2017). Warren (2011) argues that the police are the most available target of frustration with social and political institutions because they are the most visible and accessible agents of the state. Kurds in Turkey, who are more alienated from the state than Turks because of their problematic history 
with the Turkish state, have a more negative view of the police. Our results therefore support the findings in the existing literature suggesting that the strength of people's identification with the state determines their perceptions of the police (Marenin 1985, Olivera and Murphy 2015), especially in divided societies such as Turkey (Roche et al. 2017).

Along the same lines, the differences between Kurds and Turks in terms of their views regarding the police might be accounted for with Weitzer and Tuch's extension of the group position thesis. Weitzer and Tuch (2006) argue that dominant ethnic groups perceive the police as an institution allied with their interests, while minorities tend to see the police as a force that contributes to their subordination. Statistics reveal considerable differences between Kurds and Turks in terms of their socioeconomic status in Turkey. For comparison, the illiteracy rate of Kurds (17\%) is higher than that of Turks (4\%), and the percentage of households with an income of less than $700 \mathrm{TL}$ is higher among Kurdish families (51.9\%) than Turkish families (32.8\%) (KONDA 2011). TUIK (2017) unemployment statistics indicate that the region consisting of Mardin, Batman, Şırnak, and Siirt (cities in Turkey with a predominantly Kurdish population) had a $28.3 \%$ unemployment rate in 2016 , whereas the overall unemployment rate for Turkey was $10.9 \%$ for the same year. Furthermore, as opposed to $3.2 \%$ of Turks, $23.4 \%$ of Kurds report that they have fewer opportunities to express their identity (KONDA 2011). In relation to these figures, more Kurds than Turks believe that the causes of the Kurdish Question include underdevelopment (18.5\% vs. $12.3 \%)$ and discrimination against Kurds $(25.3 \%$ vs. $5.5 \%$ ) (KONDA 2011). Therefore, Kurds are more likely to see the state as responsible for their subordinate position. Given that Turks hold more positive views of the police than Kurds, the group position theory would suggest that Turks, as the socio-economically privileged ethnic group in Turkey, are more likely to position themselves alongside the state (Roche et al. 2017) and therefore see the police as a state institution protecting their interests. Kurds, on the other hand, as the socioeconomically subordinate ethnic group, are more likely to position themselves against the state and therefore view the police as agents of the state, furthering their subordinate position.

During the survey period (March 4 - May 5, 2015), negotiations between the Turkish state and Abdullah Ocalan (the imprisoned leader of the PKK) aimed at seeking a peaceful solution to Turkey's Kurdish Question were ongoing. Therefore, our survey was conducted when armed clashes between state security forces and the PKK were minimized, and Kurds' relationship with state security forces was significantly improved. Our analysis of the 2015 Human Rights Violations Report of the Human Rights Organization (IHD) offers support for this assertion. The 2015 IHD report shows that, in Diyarbakir, between January 1 and June 30 of 2015, security forces detained 285 people, 10 of whom were minors. During the same period, the same report cites only five claims of torture by security forces in Diyarbakır. After clashes between the PKK and the Turkish state resumed in July of 2015, security forces in Diyarbakır detained 855 people between July 1 and December 31 of 2015, 32 of whom were minors. During the same period, it was claimed that 38 people were tortured or beaten by security forces in this city (IHD 2015).

The persistence of negative perceptions of the police, even while negotiations between the PKK and the Turkish state were continuing and there was a relatively 
conflict-free environment, indicates that Kurds' perceptions of the police were resilient to short-term changes in the political atmosphere. This leads us to conclude that short-term changes in the Turkish state's policy towards Kurds did not affect their perceptions of the police. As previously mentioned, citizens might have negative opinions about an institution, regardless of its fairness, if they do not believe in its legitimacy (Easton 1965, Cann and Yates 2008). Kurds identify less with and are more alienated from the state than Turks because of their problematic history with the Turkish state, during which they experienced many human rights violations by the police. This historical baggage might have caused Kurds to believe that the police have not treated them in accordance with existing law - in other words, in a lawful manner. Therefore, regardless of its fairness, Kurds do not perceive the state institution of the police to be legitimate, leading them to hold an overall more negative view of the police. This lends support to the argument that people's perceptions of police legitimacy might determine their general views of the police, in contrast to the procedural justice perspective, which argues that the fairness of the police determines people's perceptions of police legitimacy and thus their views of the police.

We also argue that, in Turkey, the differences between Kurds and Turks and between ruling party voters and opposition party voters, in terms of their perceptions of the police - which is supposedly an impartial state institution - indicate polarization. This reflects the problematic relationship between the Turkish state and Kurds, as well as a crystallization of the perception among opposition party voters that state institutions are not impartial. However, in divided societies such as Turkey, the state is required to play the role of arbiter between different identity groups. If it is generally considered by disadvantaged identity groups that the state supports one group over another, the state might lose public trust. Our findings show that Kurds and opposition party voters are less likely than Turks and AKP voters, respectively, to see the state as a neutral arbiter, indicating that major societal groups might be losing their trust in the state.

\footnotetext{
${ }^{1}$ For example, Oliveira and Murphy (2015) found that those who identified more strongly with Australia and Australian culture have a more positive view of the police.

2 The World Values Survey asks the following question to measure people's confidence in the police: 'I am going to name a number of organizations. For each one, could you tell me how much confidence you have in them: is it a great deal of confidence, quite a lot of confidence, not very much confidence or none at all?' One of the organizations in this list is the police. The participant is expected to provide a number between ' 1 ' and ' 4 '. $(1=$ a great deal; $4=$ none at all).

${ }^{3}$ Sunni Muslims comprise the largest belief group in Turkey. Sunni Muslims adhere to the five pillars of Islam, including the declaration of faith, praying five times a day, fasting during Ramadan, pilgrimage to Mecca, and Zakat (giving alms) (Martinovic and Verkuyten 2016).

${ }^{4}$ Alevism is thought to be a sect of Islam, combining elements of Shi' ite and Sufi Islam, causing the Alevis to be considered heterodox Muslims. Alevis constitute the second largest belief group in Turkey, numbering up to 15 million of a population of approximately 75 million people (Borovali and Boyraz 2014). This makes Alevis the largest religious minority in Turkey.

${ }^{5}$ Although the Turkish Statistical Institute does not ask people their identity in censuses, several studies estimate the Kurdish population is somewhere between $14.5 \%$ and over $20 \%$ of the total population of Turkey (Karimova and Derevell 2001, Koç, Hancioglu and Cavlin
} 
2008, the World Factbook 2016). Therefore, we conclude that our survey sample is fairly representative of Kurds and Turks in Turkey.

${ }^{6}$ The World Justice Project, in their words, is "an independent and multidisciplinary organization measuring working to advance rule of law in the world". The organization has created an index (the WJP Rule of Law Index) aiming to measure how the rule of law is viewed by the general public in 102 countries.

${ }^{7}$ This survey question might be considered to be "double-barreled," since participants cannot distinguish between dyads - Kurds/ Turks and Alevis/ Sunnis - in answering the question. However, this question primarily aims to measure people's perceptions about the impartiality of the police rather than which groups the police might be more hostile towards. Therefore, this particular question - though the wording creates a measurement/ operationalization problem - is essential for the development of the independent variable.

${ }^{8}$ AKP voters $($ Mean $=3.5513)$ vs. MHP voters $($ Mean $=2.7532)$. 


\section{References}

Açikel, F. and Ateş, K., 2011. Ambivalent citizens: the Alevi as the 'authentic self' and the 'stigmatized other' of Turkish nationalism. European societies, 13 (5), 713-733.

Albrecht, H.J., 1997. "Ethnic minorities, crime and criminal justice in Germany." In Ethnicity, crime and immigration: comparative and cross-national perspectives, edited by M. Tonry, 31-99. Chicago: University of Chicago Press.

Alpert, G. P. and Dunham, R.G., 1992. Policing urban America. Prospect Heights, IL: Waveland Press.

Anderson, C. and Tverdova, Y.V., 2001. Winners, losers, and attitudes about government in contemporary democracies. International political science review, 22 (4), 321-338.

Aslan, S., 2011. Everyday forms of state power and the Kurds in the early Turkish Republic. International journal of middle eastern studies, 43 (1), 75 93.

Beetham, D., 1991. The legitimation of power. London, U.K.: Macmillan.

Bilali, R., Celik, B., and Ok, E., 2014. Psychological asymmetry in minority-majority relations at different stages of ethnic conflict. International journal of intercultural relations, 43, 253-64.

Bjornstrom, E. E. S., 2015. Race-ethnicity, nativity, neighborhood context and reports of unfair treatment by police. Ethnic and racial studies, 38 (12), 2019-2036.

Bobo, L. and Tuan, M., 2006. Prejudice in politics: group position, public opinion, and the Wisconsin Treaty Rights dispute. Cambridge, MA: Harvard University Press.

Boroval1, M. and Boyraz, C., 2014. Turkish secularism and Islam: a difficult dialogue with Alevis. Philosophy and social criticism, 40 (4-5), 479-488.

Bradford, B., Jackson, J., and Stanko, E., 2009. Contact and confidence: revisiting the impact of public encounters with the police. Policing and society, 19 (1), $20-46$.

Bradford, B., Murphy, K., and Jackson J., 2014. Officers as mirrors: policing, procedural justice and the (re)production of social identity. British journal of criminology, 54 (4), 527-550.

Brewer, J.D., 1991. Policing in divided societies: theorizing a type of policing. Policing \& society, 1 (3), 179-191.

Brown, B. and Benedict, W. R. E., 2002. Perceptions of the police: past findings, 
methodological issues, conceptual issues and policy implications. Policing, 25 (3), 543-580.

Browning, S. L., et al., 1994. Race and getting hassled by the police: a research note." Policing: an international journal of police strategies \& management, 17 (1), $1-11$.

Buckler, K. and Unnever, J. D., 2008. Racial and ethnic perceptions of injustice: testing the core hypotheses of comparative conflict theory. Journal of criminal justice, 36 (3): 270-278.

Canefe, N., 2008. Turkish nationalism and the Kurdish question: nation, state and securitization of communal identities in a regional context. South European society \& politics, 13 (3), 391-398.

Cann, D. M. and Yates, J., 2008. Homegrown institutional legitimacy: assessing citizens' diffuse support for state courts. American politics research, 36 (2), 297-329.

Cao, L. and Zhao, J. S., 2005. Confidence in the police in Latin America. Journal of criminal justice, 33 (5), 403-412.

Cao, L. and Hou, C., 2001. A comparison of confidence in the police in China and in the United States. Journal of criminal justice, 29 (2), 87-99.

Chakraborti, N. and Garland, J., 2003. Under-researched and overlooked: an exploration of the attitudes of rural minority ethnic communities towards crime, community safety and the criminal justice system. Journal of ethnic and migration studies, 29 (3), 563-572.

Cochran, J. C. and Warren, P. Y., 2012. Racial, ethnic, and gender differences in perceptions of the police: the salience of officer race within the context of racial profiling. Journal of contemporary criminal justice, 28 (2), 206-227.

Correia, M. E., Reisig, M. D., and Lovrich, N. P., 1996. Public perceptions of state police: an analysis of individual-level and contextual variables. Journal of criminal justice, 24 (1), 17-28.

Çelik, A. B., 2005. Transnationalization of human rights norms and its impact on internally displaced Kurds. Human rights quarterly, 27 (3), 969-997.

Çelik, A,B., Bilali, R., and Iqbal, Y., 2017. Patterns of 'Othering' in Turkey: a study of ethnic, ideological, and sectarian polarization. South european society and politics, 22 (2), 217-238

Cureton, S., 2000. Justifiable arrests or discretionary justice: predictors of racial arrest differentials. Journal of black studies, 30 (5), 703-19.

Das, D., 1983. Conflict views on policing: an evaluation. American journal of police, 3 (1), 51-81. 
Dhont, K., Cornelis, I., and Van Hiel, A., 2010. Interracial public-police contact: relationships with police officers' racial and work-related attitudes and behavior. International journal of intercultural relations, 34 (6), 551-560.

Easton, D., 1965. A systems analysis of political life. New York, NY: Wiley.

Engel, R.S., 2005. Citizens' perceptions of distributive and procedural injustice during traffic stops with police. Journal of research in crime and delinquency, 42 (4), 445-481.

Enloe, C., 1980. Ethnic soldiers: state security in divided societies. Athens: University of Georgia Press.

Erdemir, A., 2005. Tradition and modernity: Alevis' ambiguous terms and Turkey's ambivalent subjects. Middle eastern studies, 41 (6), 937-951.

Eschholz, S., et al., 2002. Race and attitudes toward the police: assessing the effects of watching. Journal of criminal justice, 30 (4), 327-341.

European Union, 2010. Minorities and Discrimination Survey 2010: Police Stop and Minorities.

Frank, J., Smith, B. W., and Novak, K., 2005. Exploring the basis of citizens' attitudes toward the police. Police quarterly, 8 (2), 206-28.

Gibson, J., 1991. Institutional legitimacy, procedural justice, and compliance with Supreme Court decisions: A question of causality. Law \& society review, 25 (3), 631-636.

Göral, Ö. S., Işık, A., and Kaya, Ö., 2013. The unspoken truth: enforced disappearances. İstanbul: Truth Justice Memory Center.

Guttstadt Görgü, C., 2013. "Depriving non-Muslims of citizenship as a part of the Turkification policy in the early years of the Turkish Republic: the case of Turkish Jews and its consequences during the Holocaust." In Turkey beyond nationalism: towards post-nationalist identities, edited by $\mathrm{H}$. Kieser and K. Oktem, 50-57. London: I\&B Tauris.

Hasisi, B. and Weitzer, R., 2007. Police relations with Arabs and Jews in Israel. British journal of criminology, 47 (5), 728-745.

IHD. 2015. 2015 İnsan hakları ihlalleri raporu. [2015 Human rights violations report]. Available from: http://www.insanhaklaridernegi.org/wpcontent/uploads/2016/03/\%C4\%B0HD-2015-RAPORU.pdf [Accessed 14 April 2017].

Jang, H., Joo, H. J., and Zhao, J., 2010. Determinants of public confidence in police: an international perspective. Journal of criminal justice, 38 (1), 57-68. 
Kaariainen, J. T., 2007. Trust in the police in 16 European countries: a multilevel analysis. European journal of criminology, 4 (4), 409-435.

Karakoç, E., 2013. Ethnicity and trust in national and international institutions: Kurdish attitudes toward political institutions in Turkey, Turkish studies, 14 (1), 92-114.

Karimova, N. and Derevell, E., 2001. Minorities in Turkey. The Swedish Institute of International Affairs, Occasional papers, 19, 1-24.

Kırmızıdağ, N., 2015. Research on public trust in the police in Turkey. Istanbul: TESEV.

Kizilkan-Kisacik, Z. B., 2013. The impact of the EU on minority rights: the Kurds as a case. In: C. Gunes and W. Zeydanlioglu, eds. The Kurdish question in Turkey: new perspectives on violence, representation, and reconciliation. New York: Routledge, 205-224.

Koç, I., Hancioglu, A. and Cavlin, A., 2008. Demographic differentials and demographic integration of Turkish and Kurdish populations in Turkey. Population research and policy review, 27 (4), 447-57

Koper, C., 1995. Just enough police presence: reducing crime and disorderly behavior by optimizing patrol time on crime hot spots. Justice quarterly, 12, 649-672.

KONDA. 2011. Kürt Meselesi'nde algı ve beklentiler araştırmast [The research on perceptions and expectations regarding the Kurdish Question]. Available from: http://konda.com.tr/wpcontent/uploads/2017/02/2011_06_KONDA_Kurt_Mes elesinde_Algi_ve_Beklentiler.pdf [Accessed 10 September 2017].

Kusow, A. M., Wilson, L. C., and Martin, D. E., 1997. Determinants of citizen satisfaction with the police: the effects of residential location. Policing: an international journal of police strategies \& management, 20 (4), 655-64.

Lai, Y. L. and Zhao, J. S., 2010. The impact of race/ethnicity, neighborhood context, and police/citizen interaction on residents' attitudes toward the police. Journal of criminal justice, 38 (4), 685-692.

Lehohla, P., 2015. Public perceptions about crime prevention and the criminal justice system: in-depth analysis of the Victims of Crime Survey data. Available from:

http://www.statssa.gov.za/publications/Report-03-40-03/Report-03-40032014.pdf [Accessed 4 February 2017].

Manning P.K., 2010. Democratic policing in a changing world. Boulder, CO: Paradigm Publishers.

Marenin, O., 1985. Police performance and state rule. Comparative politics, 18 (1), 101-22. 
Martinovic, B. and Verkuyten, M., 2016. Inter-religious feelings of Sunni and Alevi Muslim minorities: the role of religious commitment and host national identification. International journal of intercultural relations, 52, 1-12.

McGloin, J.M., 2003. Shifting paradigms: policing in Northern Ireland. Policing: an international journal of police strategies \& management, 26 (1), 118-143.

Murphy, K. and Cherney, A., 2011. Fostering cooperation with the police: how do ethnic minorities in Australia respond to procedural justice-based policing? The Australian and New Zealand journal of criminology, 44 (2), 235-257.

Myhill, A., and Bradford, B., 2012. Can police enhance public confidence by improving quality of service? Results from two surveys in England and Wales. Policing \& society, 22 (4), 397-425.

O'Connor, C. D., 2008. Citizen attitudes toward the police in Canada. Policing: an international journal of police strategies \& management, 31 (4), 578-595.

Oliveira, A., and Murphy, K., 2015. Race, social identity, and perceptions of police bias. Race and justice, 5 (3), 259-277.

Public perceptions of the police, PCSPs and the Northern Ireland Policing Board Northern Ireland Policing Board. Available from: https://www.nipolicingboard.org.uk/sites/nipb/files/media-files/omnibussurvey-april-2016.pdf [Accessed 24 February 2017].

Roche, S., Özaşç1lar, M., and Bilen Ö., 2017. "Why may police disobey the law? How divisions in society are a source of moral right to do bad: the case of Turkey." In Police-citizen relations across the world, edited by D. Oberwittler, 220243. New York: Routledge.

Roche, S., and Roux, G., 2017. The silver bullet to "good policing": a mirage: an analysis of the effects of political ideology and ethnic identity on procedural justice. Policing: an international journal, 40 (3), 514-528.

Rocque, M., 2011. Racial disparities in the criminal justice system and perceptions of legitimacy: a theoretical linkage. Race and justice, 1 (3), 292-315.

Rosenbaum, D. P., et al., 2005. Attitudes toward the police: the effects of direct and vicarious experience. Police quarterly, 8 (3), 343-365.

Roux, G., Roche, S., and Astor, S., 2011. Minorities and trust in the Criminal Justice. French case study. Pacte-Institute of Political Science, University of

Grenoble. Available from: http://www.pacte-grenoble.fr/wpcontent/uploads/pdf_RAPPORT_EUROJUSTIS_opinion_poll_final.pdf [Accessed 20 February 2017].

Sampson, R. J., and Laub, J. H., 1993. Structural variations in juvenile court processing: inequality, the underclass, and social control. Law and society 
review, 27 (2), 285-212.

Sarigil, Z. and Karakoç, E., 2017. Inter-ethnic (in)tolerance between Turks and Kurds: implications for Turkish democratization. South european society and politics, $22(2), 197-216$.

Saraçoğlu, C., 2009. 'Exclusive recognition': the new dimensions of the question of ethnicity and nationalism in Turkey. Ethnic and racial studies, 32 (4), 640658 .

Saraçoğlu, C., 2010. The changing image of the Kurds in Turkish cities: middle-class perceptions of Kurdish migrants in Izmir. Patterns of Prejudice, 44 (3), 239260.

Skogan, W. G., 2012. Assessing asymmetry: the life course of a research project. Policing \& society, 22 (3), 270-279.

Smith, B. W., 2005. Ethno-racial political transition and citizen satisfaction with police. Policing: an international journal of police strategies \& management, $28(2), 242-54$.

Spehr, S. and Kassenova, N., 2012. Kazakhstan: constructing identity in a post-Soviet society. Asian ethnicity, 13 (2), 135-151.

Sözcü, 2015. Hangi ilde, kaç polis var? [How many police officer are present in each city?]. Available from: http://www.sozcu.com.tr/2015/gundem/hangi-ilde-kacpolis-var-978817/ [Accessed 10 September 2016]

Sunshine, J. and Tyler, T. R., 2003. The role of procedural justice and legitimacy in shaping public support for policing. Law and society review, 37 (3), 513-548.

Tamanaha, B. 2004. On the rule of law: history, politics, theory. Cambridge, U.K.: Cambridge University Press.

Tankebe, J., 2013. Viewing things differently: the dimensions of public perceptions of police legitimacy. Criminology, 51 (1), 103-135.

The World Factbook. 2017. Middle East: Turkey. Available from: https://www.cia.gov/library/publications/the-world-factbook/geos/tu.html [Accessed 5 February 2017]

The World Justice Project. 2014. The rule of law index 2014. Available from: https://worldjusticeproject.org/sites/default/files/files/wjp_rule_of_law_index 2014_report.pdf [Accessed 15 August 2015].

TUIK. 2016. İşgücü istatistikleri, 2016 [Labor force statistics, 2016]. Available from: http://www.tuik.gov.tr/PreHaberBultenleri.do?id=24635 [Accessed 22 September 2017].

Tyler, T., 1990. Why people obey the law. New Haven, CT: Yale University Press. 
Tyler, T. R., 2005. Policing in black and white: ethnic group differences in trust and confidence in the police. Police quarterly, 8 (3), 322-342.

Van Craen, M., 2012. Determinants of ethnic minority confidence in the police. Journal of ethnic and migration studies, 38 (7), 1029-1047.

Waddington, P.A.J., Williams, K., Wright M., and Newburn T., 2013. Dissension in public evaluations of the police. Policing \& society, 25 (2), 212-235.

Warren, P. Y., 2011. Perceptions of police disrespect during vehicle stops: a racebased analysis. Crime \& delinquency, 57 (3), 356-376.

Weitzer, R. and Tuch, S. A., 1999. Race, class, and perceptions of discrimination by the police. Crime \& delinquency, 45 (4), 494-507.

Weitzer, R. and Tuch, S. A., 2005. Determinants of public satisfaction with the police. Police quarterly, 8 (3), 279-297.

Weitzer, R. and Tuch, S. A., 2006. Race and policing in America. Cambridge: Cambridge University Press.

World Values Survey. 2012. Available from: http://www.worldvaluessurvey.org/WVSDocumentationWV6.jsp [Accessed 27 August 2016]

Wortley, S., 1996. Justice for all? Race and perceptions of bias in the Ontario criminal justice system: a Toronto study. Canadian journal of criminology, 38, 439467.

Wortley, S. and Owusu-Bempah, A., 2009. Unequal before the law: immigrant and racial minority perceptions of the Canadian criminal justice system. Journal of international migration and integration, 10 (4), 447-473.

Wu, Y., 2014. Race/ethnicity and perceptions of the police: a comparison of White, Black, Asian and Hispanic Americans. Policing and society, 24 (2), 135-157.

Yegen, M., 2009. Prospective Turks or pseudo citizens: Kurds in Turkey. Middle east journal, 63 (4), 597-615. 
Appendix 1. Distribution of population in Turkey according to the level of development

\begin{tabular}{|l|l|l|l|l|}
\hline & & Notal & $\begin{array}{l}\text { Share of } \\
\text { Urban } \\
\text { Population }\end{array}$ & $\begin{array}{l}\text { Share of } \\
\text { Rural } \\
\text { Population }\end{array}$ \\
\hline TR1 & Istanbul & 13.624 .240 & 0,990 & 0,010 \\
\hline TR2 & West Marmara & 3.210 .147 & 0,636 & 0,364 \\
\hline TR3 & Aegean & 9.687 .692 & 0,732 & 0,268 \\
\hline TR4 & East Marmara & 6.952 .685 & 0,848 & 0,152 \\
\hline TR5 & West Anatolia & 7.163 .453 & 0,901 & 0,099 \\
\hline TR6 & Mediterranean & 9.495 .788 & 0,715 & 0,285 \\
\hline TR7 & Central Anatolia & 3.843 .731 & 0,712 & 0,288 \\
\hline TR8 & West Black Sea & 4.477 .107 & 0,603 & 0,397 \\
\hline TR9 & East Black Sea & 2.513 .021 & 0,572 & 0,428 \\
\hline TRA & Northeast Anatolia & 2.230 .394 & 0,551 & 0,449 \\
\hline TRB & Mideast Anatolia & 3.709 .838 & 0,572 & 0,428 \\
\hline TRC & Southeast Anatolia & 7.816 .173 & 0,691 & 0,309 \\
\hline & & & & \\
& Total & 74.724 .269 & 0,768 & 0,232 \\
\hline
\end{tabular}

Notes: 2011 Population Registration System Based on Address, TUIK

Appendix 2. The distribution of sample across the regions as provided by the TUIK

\begin{tabular}{|l|l|c|c|c|c|}
\hline & & & & \\
& & $\begin{array}{c}\text { Total } \\
\text { Number of } \\
\text { Participants }\end{array}$ & $\begin{array}{c}\text { Number of } \\
\text { Participants } \\
\text { in Urban } \\
\text { Centers }\end{array}$ & $\begin{array}{c}\text { Number of } \\
\text { Participants } \\
\text { in Semi- } \\
\text { Rural } \\
\text { Centers }\end{array}$ & $\begin{array}{c}\text { Number of } \\
\text { Particiapants } \\
\text { in Rural } \\
\text { Centers }\end{array}$ \\
\hline TR1 & İstanbul & 331 & 321 & 10 & 0 \\
\hline TR2 & West Marmara (Balikesir) & 74 & 66 & 0 & 8 \\
\hline TR3 & Aegean (İzmir) & 231 & 210 & 21 & 0 \\
\hline TR4 & East Marmara (Bursa) & 176 & 128 & 48 & 0 \\
\hline TR5 & West Anatolia (Ankara) & 176 & 176 & 0 & 0 \\
\hline TR6 & Mediterranean (Adana) & 231 & 184 & 41 & 6 \\
\hline TR7 & Central Anatolia (Kayseri) & 86 & 60 & 22 & 4 \\
\hline TR8 & West Black Sea (Samsun) & 108 & 69 & 9 & 30 \\
\hline TR9 & East Black Sea (Trabzon) & 56 & 43 & 1 & 12 \\
\hline TRA & Northeast Anatolia (Erzurum) & 55 & 29 & 12 & 14 \\
\hline TRB & Mideast Anatolia (Malatya) & 88 & 61 & 2 & 25 \\
\hline TRC & Southeast Anatolia (Diyarbak1r) & 192 & 142 & 34 & 16 \\
\hline & Total & 1804 & 1489 & 200 & 115 \\
\hline
\end{tabular}

